\title{
Progressive Law as an Alternative Solution to Eradicate Money Laundering from Drug-Related Transactions
}

\author{
Juna Karo Karo ${ }^{1}$, Bismar Nasution ${ }^{2}$, Sunarmi $^{3}$, Mahmud Mulyadi ${ }^{4}$ \\ \{junajunakaban@ymail.com ${ }^{1}$ \} \\ Universitas Sumatera Utara, Indonesia ${ }^{1,2,3,4}$
}

\begin{abstract}
Cases of drug-related criminal offenses are often accompanied by money laundering, but in practice eradication of money laundering from drug-related criminal offenses often encounters problems due to the existing regulations. Thus, a progressive law is required, to allow investigation on the money laundering crimes when there are "assets that are known or reasonably suspected to be proceeds of criminal offences". In addition, coordination between the Police and Indonesian Financial Transaction Reports and Analysis Centre (INTRAC) can be realized through an integrated function to support the law enforcement institutions to eradicate money laundering.
\end{abstract}

Keywords: Progressive Law, Money Laundering, Drugs

\section{Introduction}

The increasing practice of money laundering, especially in Indonesia, has caused such losses to the state that clear efforts are needed to overcome them. Considering the increasing global competition in the financial services industry, some parties continue to question the efficiency of anti-money laundering efforts. International efforts have been carried out.

The practice of money laundering has received considerable attention from countries all over the world. Moreover, the money in the practice of money laundering comes from serious crimes such as corruption, drug trafficking, and terrorism. Money laundering related to drug crimes is one of the predicate crimes that underlie money laundering crimes. Efforts to eradicate money laundering often encounter obstacles, particularly the legal provisions in its handling. The court proceedings on drug-related criminal offenses often reveal cases of money laundering. Public prosecutors in charge of such cases should be given special authority because these drugrelated criminal offenses are categorized as serious crimes. Therefore, a regulation to accommodate the implementation of money laundering eradication is needed, that the eradication could depart from the current legal provisions which are still rigid and need to be reformed [1].

Prof. Satjipto argues that the culmination of legal method is when people dare to break free from the shackles of legislation and find new progressive ways. In this context, we no longer perform arithmetic in mathematics or spell out legislature articles; but rather act creatively and make the leap. We use the term "leap" to define that it is not merely following or bound by past habits (commonly referred to as jurisprudence or stare decisis) but by producing entirely new 
decisions. Thus, a legalistic, positive-analytical method of law is referred to as rulemaking, while the creative and intuitive thinking above is referred to as rule-breaking [2].

Based on the background stated above, the problem of this study is formulated into the question "How necessary is a progressive law in supporting the eradication efforts of money laundering derived from drug-related criminal offenses?" With the effectiveness of the eradication of money laundering practices, there will be less circulation of illegal narcotics in Indonesia.

\section{Research Method}

Based on the objective of the research, this study uses a normative legal method, through which the law is conceptualized as norms, principles, or dogmas. According to Soerjono Soekanto, normative legal research consists of research on legal principles, legal systematics, levels of legal synchronization, legal history, and comparative law. Two approaches were used in this study. The first one was a statutory approach carried out by examining all laws and regulations related to the legal issues being handled. The second one was a conceptual approach that departed from the views and doctrines developed in the science of law.

\section{Results and Discussion}

\subsection{Problems of Drug Trafficking-Related Money Laundering Practices}

Money Laundering can be defined as money bleaching, money smuggling, or cleaning up money from illegal (dirty) transactions [3]. The term "money laundering" can be referred to using various terms, such as dirty money, hot money, illegal money, or illicit money.

According to Black's Law Dictionary, the term Money Laundering means:

"Terms used to describe investment or other transfers of money flowing from racketeering, drug transactions, and other illegal sources into legitimate channels so that its original source cannot be traced". Money Laundering is a federal crime. 18 USCA.195 [4].

Money laundering should be eradicated because it can always be attached to a predicate crime, leading to other crimes. A predicate crime is a principal offense that will determine whether a person has been proven to have violated the law. According to the Indonesian Financial Transaction Reports and Analysis Centre (INTRAC), the common predicate crimes in Indonesia are corruption and drug trafficking which later develop into money laundering offenses.

Article 1 point 1 of Law Number 8 of 2010 concerning Prevention and Eradication of Money Laundering Offenses stipulates that Money Laundering is any act that fulfills the elements of a criminal offense following the provisions of this Law. Furthermore, Article 3 of Law Number 8 of 2010 stipulates that any person who places, transfers, diverts, spends, pays, grants, entrusts, takes abroad, changes the form, exchanges with currency or securities, or other actions on Assets known or reasonably suspected to be proceeds of criminal offenses as referred to in Article 2 Paragraph (1) with the aim of hiding or concealing the origin of the Assets shall 
be sentenced for money laundering offenses with a maximum imprisonment of 20 (twenty) years and a maximum fine of IDR 10,000,000,000.00 (ten billion rupiah) [5].

Motivated by these problems, the United Nations Convention Against Illicit Traffic in Narcotic Drugs and Psychotropic Substances was issued as the pinnacle of the eradication of money laundering offenses derived from illicit narcotics and psychotropic trafficking. This convention requires every country that has ratified it to criminalize money laundering through statutory regulations.

\subsection{Finding Money Laundering Practices from Drug-Related Criminal Offenses}

Based on the elucidation of Article 74 of the Law on Money Laundering Criminal Offenses, investigators of predicate crime can investigate a money-laundering criminal offense if they find sufficient initial evidence of the occurrence of money laundering practice when investigating its predicate crime. Thus, investigation on a money laundering criminal offense shall not be carried out if investigation of its predicate crime has not been conducted.

Therefore, if during the prosecution of drug-related criminal offenses in court, investigators found a case of money laundering, they can proceed with an investigation on such a crime as long as they have sufficient related preliminary evidence. Furthermore, it can also be emphasized that the investigation on a money laundering criminal offense shall not (absolutely) be carried out if investigation on its predicate crime has not been conducted.

Moreover, if during a court trial on a drug crime, a case of money laundering from drugrelated criminal offenses is found, then, based on Article 69 of the Law on Money Laundering Criminal Offenses, the law enforcement officers are not obliged to prove the predicate crime in advance. In the case of drug crime, investigations, prosecutions, and examinations in court proceedings against the money laundering criminal offense can be conducted.

The process of handling money laundering criminal offenses involves a relatively new institution, namely the Indonesian Financial Transaction Reports and Analysis Centre (INTRAC). The involvement of the INTRAC is more on providing confidential financial information (financial intelligence) to law enforcers. The establishment of the INTRAC as a Financial Intelligence Unit (FIU) serves as a central institution that coordinates measures in handling money laundering [6]. INTRAC performs investigative functions, including collecting, storing, analyzing, and evaluating transaction information that is suspected and presumed to be a financial crime. The role of INTRAC is to meet the international standards of the Anti-Money Laundering (AML) regime in Indonesia. As the leading institution in tackling money laundering criminal offenses, INTRAC should have a concrete role in fighting money laundering, especially with such complex modus operandi. The role of the INTRAC will affect the capability of Indonesia in preventing and eradicating money laundering practices. To make it effective, sustainable support and coordination from all parties involved is obviously required, especially from the financial institutions and law enforcement institutions. The coordination between the two institutions can be realized through an integrated function including receiving, analyzing all financial-related information, and submitting to law enforcement institutions for further action [7]. 


\subsection{Can the Public Prosecutor Directly Investigate/Prosecute a Money Laundering Case during the Trial of Drug Crimes Based on Facts just Revealed in Court?}

The relationship between money laundering and the predicate crime can be seen in Article 2 Paragraph (1) letter a which states that proceeds of crime are assets obtained from a criminal offense committed in the territory of the Republic of Indonesia or outside the territory of the Republic of Indonesia, and that such offense also belongs to a criminal offense under Indonesian law. Thus, it is appropriate to argue that there will be no money laundering if there is no crime that generates money/assets (no crime no money laundering). Based on Article 1 of the Law on Money Laundering Criminal Offenses which has been described above, all suspected assets derived from the proceeds of crime which are hidden or disguised are money laundering criminal offenses. On the other hand, the money laundering criminal offense is an independent crime because it has been formulated independently in Articles 3 and 6 of the Law on Money Laundering Criminal Offenses. The process of money laundering does not have to wait for a predicate crime to be decided. This is very appropriate because in Articles 3 and 6 of Law on Money Laundering Criminal Offenses, the definition of money laundering is "assets that are known or reasonably suspected to be proceeds of criminal offenses", but not "assets from the proceeds of criminal offenses". Thus, with only an allegation that the assets are derived from the proceeds of criminal offenses, the money laundering crime can be charged as long as all the criminal elements and proceedings have been fulfilled.

Determining predicate crimes on money laundering in the process of law enforcement in Indonesia is difficult because the Indonesian criminal law system adheres to the principle that for an act to be declared a crime, it must go through a legal mechanism, which is marked by a judge's decision with permanent legal force. This means that before the judge's decision has permanent legal force, an act alleged against the suspect is in the form of a core crime cannot be categorized as a crime. For example, in corruption cases, money laundering allegations accused by the prosecutor shall be transferred to Police investigators. If the proceeds of an act which cannot be categorized as a crime, then the element of the "proceeds of a criminal act" as the condition for money laundering is not fulfilled. The legal consequence of not meeting these prerequisites is no evidence of money laundering.

In the context of no prior evidence on the predicate crime, the Police investigators, in conducting investigations on Money Laundering Criminal Offenses, have violated the principle of presumption of innocence and the principle of non-self-incrimination. The suspect/defendant of money laundering criminal offenses has been deemed guilty of a predicate crime without prior evidence of his/her fault because the judge's decision already has permanent legal force. Therefore, based on this principle, perpetrators of money laundering can only be charged with the application of the principle of continuous acts (delictum continuatum/ voortgezettehandeling). The principle states that acts continue when someone commits acts (either crimes or offenses), and those acts are somehow related should be deemed as continuous acts [8].

When a comparative study on the proof system as one of the repressive actions done by law enforcement officers against the perpetrators of money laundering is conducted in other countries, e.g. the United States, several significant differences are found. The United States, for example, courageously state that supporting evidence or guidance (circumstantial evidence) is sufficient to justify the presence of money laundering elements. Meanwhile, in Indonesia, evidence is always based on its subjective element (mens rea) and its objective element (actus reus). In mens rea, the elements to be proven are knowledge and intent. The two elements are 
always closely related in revealing that the suspect, the prosecuted, or the defendant knows the original source of the money and knows the purpose of conducting the transaction. Thus, it can be seen clearly that the proof system plays a very important role and is difficult to prove the predicate offense because money laundering is a follow-up crime.

Thus, the proceeds of criminal offenses, which constitute an element of money laundering, are minimized by adding the words "that are known or reasonably suspected". The elucidation of Article 3 of the Law on Money Laundering Criminal Offenses can clearly be interpreted that the proceeds of criminal offenses, at a minimum, have indicated initial evidence of the occurrence of a criminal offense. In other words, the elucidation of the article clearly implies that the predicate crime as the core crime of Money Laundering Criminal Offenses does not need to be proven in advance because preliminary evidence has been sufficient. This becomes the basis for the eradication of money laundering criminal offenses used by the Police to investigate indications of money laundering obtained from core crimes through an audit trail.

In the case of a Money Laundering Criminal Offense, the investigators cannot simply start an investigation if there is no report from the INTRAC. Without a report from INTRAC or Bank of Indonesia (BI), the police cannot, for example, access someone's bank account. In the case of a drug criminal offense, investigators can charge the perpetrators with two counts. The first count is the prime crime and the second count is the Money Laundering Criminal Offense. These counts require INTRAC or BI to submit a report containing documents related to the case. The most important point in giving the authority of an audit trail (tracing the whereabouts of the perpetrator through tracing the trails of money transactions) to Police investigators on the indications of money laundering criminal offense from the initial criminal investigation is "sufficient initial evidence", as stated in Article 3 of the Law on Money Laundering Criminal Offenses. This article, if linked with Article 2, constructs an understanding that "assets" and "that are obtained directly or indirectly from crimes" are elements of a criminal offense. In the definition of money laundering, the construction is reduced by the presence of the words "that are known or reasonably suspected" [9].

Until recently, the provisions in Article 75 of Law Number 8 of 2010 states that "if an investigator finds sufficient initial evidence of money laundering and its predicate crime, the investigator will combine the investigation of money laundering with its predicate crime". Meanwhile, Article 74 states that "criminal investigation on money laundering shall be conducted by the investigator of the predicate crime following the provisions of the prevailing laws and regulations unless otherwise provided for in this Law". However, the writers believe that an amendment to the provisions of the regulations related to drug crimes is required, such as Law Number 35 of 2009. Moreover, it could be more progressive if there is a specific regulation regarding the handling of money laundering. As a case controller (dominus litis), a public prosecutor in finding the money laundering criminal offense during the prosecution of a drug crime can immediately prosecute the money laundering criminal offense revealed in court. This is certainly more effective than waiting for a new investigation on the predicate crime (drug crime) to be carried out. Coordination of the main investigators (Police, INTRAC, etc.) can be realized through an integrated function to receive, analyze, and submit the financial-related information to law enforcement for swift action. Thus, the eradication of the money laundering practice from drug-related criminal offenses can be carried out effectively and optimally under the principles of a fast, simple, and low-cost trial. 


\section{Conclusion}

A change in provisions should be realized to have more progressive laws and regulations relating to drug crimes. In this case, a special regulation regarding the handling of money laundering criminal offenses allows the general prosecutor, as the dominus litis in finding money laundering when carrying out prosecution of a drug crime, can immediately prosecute the money laundering criminal offense revealed in court. This is certainly more effective than waiting for a new investigation on the predicate crime (drug crime) to be carried out. Thus, the eradication of the money laundering practice from drug-related criminal offenses can be carried out effectively and optimally under the principles of a fast, simple, and low-cost trial.

\section{References}

[1] S. Raharjo, "Biarkan Hukum Mengalir," Jakarta: Kompas, 2007.

[2] P. De Cruz, "Perbandingan Sistem Hukum, Common Law, Civil Law dan Socialist Law," Bandung. Nusa Media, 2010.

[3] B. Nasution, "Bahan Ajar Hukum Rezim Anti Money Laundering." Medan, 2008.

[4] Y. Husein, "Upaya Indonesia untuk Keluar dari Daftar NCCTs," J. Huk. Bisnis, vol. 22, 2003.

[5] Pemerintah Republik Indonesia, Undang-Undang Nomor 08 Tahun 2010 tentang Pencegahan dan Pemberantasan Tindak Pidana Pencucian Uang. 2010.

[6] J. S. Jahja, "Diklat Selayang Pandang Penanggulangan Money Laundry di Indonesia," Jakarta, 2009.

[7] O. H. B. M. Hutahaean and S. Pujiyono, "Peran Penyidik Badan Narkotika Nasional (BNN) dalam Penegakan Hukum Tindak Pidana Pencucian Uang (TPPU)," Diponegoro Law J., vol. 5, no. 2, pp. 1-9, 2016.

[8] A. Alkostar, Identitas Hukum Nasional. Fakultas Hukum, Universitas Islam Indonesia, 1997.

[9] S. R. Sjahdeini and N. Safrizar, Seluk Beluk Tindak Pidana Pencucian Uang dan Pembiayaan Terorisme. Pustaka Utama Grafiti, 2004. 